\title{
Nanocrystalline Todorokite-like Manganese Oxide Produced by Bacterial Catalysis
}

\author{
Hack-Sung Kim, Pablo A. Pastén, Jean-François Gaillard, and Peter C. Stair*
}

\section{Supporting information}

\section{Materials and experimental procedures}

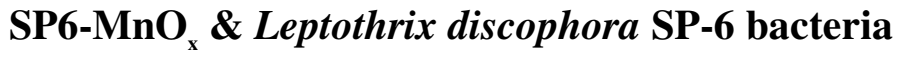

Liquid culture of Leptothrix discophora SP-6 (ATCC 51168) was grown at room temperature in MSVP/noFe medium (mineral salts, vitamins, and pyruvate; ATCC Culture Medium 1917 with no iron added) which consists of $\left(\mathrm{NH}_{4}\right)_{2} \mathrm{SO}_{4}(1.82 \mathrm{mM}), \mathrm{MgSO}_{4} \cdot 7 \mathrm{H}_{2} \mathrm{O}(0.24 \mathrm{mM}), \mathrm{CaCl}_{2} \cdot 2 \mathrm{H}_{2} \mathrm{O}(0.41 \mathrm{mM})$, $\mathrm{KH}_{2} \mathrm{PO}_{4}(0.15 \mathrm{mM}), \mathrm{Na}_{2} \mathrm{HPO}_{4}(0.21 \mathrm{mM})$, HEPES (10.00 mM, buffer, N-2-Hydroxyethylpiperazine-N'2-ethanesulfonic acid), Na-pyruvate $\left(9.06 \mathrm{mM}, \mathrm{C}_{6} \mathrm{H}_{6} \mathrm{O}_{6} \mathrm{Na}\right)$ as a carbon source, and a trace amount of several vitamins. The culture was slowly shaken $(<100 \mathrm{rpm})$ on a rotating shake table. When the culture

reached the stationary phase after $\sim 7$ days, $0.15 \mathrm{mM}$ of aqueous $\mathrm{Mn}^{2+}$ (as a stock solution of $\mathrm{MnSO}_{4}$ ) was added to the culture and bacterially oxidized for 14 days at room temperature. After this, the biogenic oxides $\left(\mathrm{SP} 6-\mathrm{MnO}_{\mathrm{x}}\right)$ were stored at liquid nitrogen temperature for X-ray absorption measurements. MSVP is a buffered medium and the $\mathrm{pH}$ of the medium varies between 7.2 to 7.3 during the bacterial growth and $\mathrm{MnO}_{\mathrm{x}}$ production.

\section{Reference $\mathrm{MnO}_{2}$ materials}

The reference $\mathrm{MnO}_{2}$ minerals available from mineral collection companies were characterized by XRD to verify their identity. The minerals used in EXAFS and UV Raman spectroscopic measurements (along with their location of origin) are: pyrolusite (Kisenge Mine, Zaire), ramsdellite 
(Mistake Mine, Yavapai County, Arizona, USA), hollandite (Ultevis, Norrbotten, Sweden), cryptomelane (Woodmine, Tennessee, USA), romanechite (also known as psilomelane, Nancy Mine, Socorro County, New Mexico, USA), chalcophanite (Mina Ojuela Mapimi, Durango, Mexico), and todorokite (Sterling Mine, Ogdensburg, Sussex County, New Jersey, USA). We used synthetic birnessite (OL-1, octahedral layered) ${ }^{1}$ as an analog of birnessite since a well-characterized birnessite mineral was not available. The OL-1 showed characteristic XRD band features of birnessite. The two strong bands centered at $1055 \mathrm{~cm}^{-1}$ and $1402 \mathrm{~cm}^{-1}$ in the Raman spectrum of synthetic birnessite are in good agreement with the reported ${ }^{2}$ symmetric and asymmetric stretching vibration of nitrate in solid $\mathrm{NaNO}_{3}$, respectively. Since nitrate is a strong Raman scatterer, traces of nitrate give distinct Raman bands. The nitrate originates from $\mathrm{NaNO}_{3}$ that was used as the $\mathrm{Na}^{+}$source for the 'synthetic birnessite' synthesis. ${ }^{3}$ The $\delta-\mathrm{MnO}_{2}$ was synthesized by precipitation from a colloidal $\mathrm{MnO}_{2}{ }^{4}$ The synthetic $\mathrm{MnO}_{2}$ showed characteristic XRD pattern, ${ }^{5,6}$ of $\delta-\mathrm{MnO}_{2}$, two broad lines at $2.43 \AA$ and $1.41 \AA$ (see Fig. S1). The buserite was synthesized according to the previously published method ${ }^{7}$. The synthetic buserite showed characteristic XRD pattern ${ }^{8}$ of buserite.

\section{TEM (transmission electron microscopy)}

A concentrated cell suspension was obtained from centrifugation and fixed on a Teflon sheet by covering with melamin resin. The fixed sheet was dried at $40^{\circ} \mathrm{C}$ for two days in a desiccator and then cured for two days at $60^{\circ} \mathrm{C}$ for the resin infiltration. Since the melamin resin is hydrophilic, this nonconventional method does not require a dehydration step before the infiltration and consequently removes the possibility of cell shrinkage. Ultrathin sections (70-90 $\mathrm{nm}$ thick) for TEM imaging were obtained with a diamond knife on an ultramicrotome (RMC MT-6000 XL). The sections were mounted on a 200 mesh formvar-coated copper grids (Structure Probe Inc.). Since no staining solution was applied to the thin section, perturbation to the cell is minimized. Micrographs were taken with a TEM instrument (JEOL $120 \mathrm{CX}$ Temscan), operating at $80 \mathrm{keV}$ and a resolution of $0.2 \mathrm{~nm}$. 


\section{EXAFS (extended X-ray absorption fine structure)}

EXAFS measurements were performed at the Advanced Photon Source, Argonne National Laboratory. The electron energy of the storage ring was $7.0 \mathrm{GeV}$ and the current was $60-100 \mathrm{~mA}$. The beam line was equipped with a $\operatorname{Si}(111)$ double crystal monochromator that was used to vary the X-ray energy from $200 \mathrm{eV}$ below to $560 \mathrm{eV}$ above the K-absorption edge of $\mathrm{Mn}(6.539 \mathrm{keV})$. The monochromator crystal faces were slightly detuned to minimize interference from higher harmonics. X-ray fluorescence from the sample was measured with a Stern-Heald "Lytle" detector equipped with a Z-1 filter (chromium foil for manganese). In order to minimize and control beam damage to the samples, all the measurements were done in quick-XAS scanning mode (Q-XAS). ${ }^{9}$ The raw EXAFS data for pyrolusite, ramsdellite, hollandite, romanechite, synthetic birnessite, $\delta-\mathrm{MnO}_{2}$, chalcophanite, todorokite, and SP6- $\mathrm{MnO}_{x}$ are shown in Fig. S2.

\section{UV Raman spectroscopy}

The UV Raman spectrometer has been described elsewhere. ${ }^{10}$ It consists of a Spex 1877 triple spectrograph with an imaging photomultiplier tube. The $244 \mathrm{~nm}$ laser excitation source for UV Raman scattering is a Lexel 95-SHG $\mathrm{Ar}^{+}$laser equipped with a frequency-doubling BBO (Beta Barium Borate, $\mathrm{BaB}_{2} \mathrm{O}_{4}$ ) crystal. An $\mathrm{AlMgF}_{2}$ coated ellipsoidal reflector using the $180^{\circ}$ scattering geometry collected the scattered light from the sample. The Raman frequency was calibrated using several reference liquids (chloroform, dichloromethane, acetonitrile) and a $\mathrm{Hg}$ lamp. All UV Raman spectra were recorded under ambient conditions.

\section{Environmental, geochemical, and geomicrobiological implications}

Our microscopic and spectroscopic studies indicate that the biologically induced Mn(II) oxidation products (located within sheaths formed around Leptothrix discophora SP-6 cells) are nanosized, todorokite-like porous $\mathrm{MnO}_{2}$. In contrast to layered or vernadite-like $\left(\delta-\mathrm{MnO}_{2}\right)$ structures, this material 
may have distinct characteristics with respect to metal scavenging and reactivity vis-à-vis organic molecules. First, tunnel $\mathrm{MnO}_{2}$ shows ${ }^{11}$ a higher catalytic activity in decomposing hydrogen peroxide than commercially available $\mathrm{MnO}_{2}$, probably attributed to a higher specific surface area. Also, todorokite-like $\mathrm{MnO}_{2}$ exhibits similar catalytic activity to its layered analog, but higher selectivity in oxidative dehydrogenation of 1-butene to 1,3-butadiene. ${ }^{12}$ Second, todorokite mineral adsorbs considerable amounts of Th and $\mathrm{U} \cdot{ }^{13}$ Moreover, structurally unidentified, biogenic $\mathrm{MnO}_{\mathrm{x}}$ produced by Leptothrix discophora SS-1, a sheath-less relative of SP-6, was reported to adsorb five times more $\mathrm{Pb}$ than the abiotic $\mathrm{MnO}_{x}$, and 500-5000 times more $\mathrm{Pb}$ than pyrolusite $\left(1 \times 1\right.$-tunnel $\left.\mathrm{MnO}_{2}\right){ }^{14}$ Thus, nanosized $\mathrm{SP} 6-\mathrm{MnO}_{x}$ probably adsorb more heavy metals $\left(\mathrm{Th}, \mathrm{U}, \mathrm{Pb}\right.$, etc) than other $\mathrm{MnO}_{\mathrm{x}}$ materials. Third, SP6- $\mathrm{MnO}_{\mathrm{x}}$ is likely to show higher activity for the $\mathrm{As}^{3+}$ oxidation to the less toxic $\mathrm{As}^{5+}$ than small-tunnel $\mathrm{MnO}_{2}$ 's. Hydrated birnessite (buserite), for example, ${ }^{15}$ with a pore size similar to todorokite ${ }^{16}$ shows better efficiency for this oxidation than small-tunnel $\mathrm{MnO}_{2}$ minerals $(1 \times 1$-tunnel $\mathrm{MnO}_{2}$ exhibits the worst efficiency). ${ }^{17}$

\section{References}

(1) Luo, J.; Zhang, Q.; Huang, A.; Giraldo, O.; Suib, S. L. Inorg. Chem. 1999, 38, 6106-6113.

(2) Zangmeister, C. D.; Pemberton, J. E. J. Phys. Chem. A 2001, 105, 3788-3795.

(3) Xia, G.-G.; Tong, W.; Tolentino, E. N.; Duan, N.-G.; Brock, S. L.; Wang, J.-Y.; Suib, S. L.; Ressler, T. Chem. Mater. 2001, 13, 1585-1592.

(4) Perez-Benito, J. F.; Brillas, E.; Pouplana, R. Inorg. Chem. 1989, 28, 390-392.

(5) Burns, R. G.; Burns, V. M. Short Course Notes - Mineral. Soc. Am. 1979, 6, 1-46.

(6) McMurdie, H. F.; Golovato, E. J. Res. Natl. Bur. Stand. 1948, 41, 589-600. 
(7) Liu, J.; Cai, J.; Son, Y.-C.; Gao, Q.; Suib, S. L.; Aindow, M. J. Phys. Chem. B 2002, 106, 9761-9768.

(8) Ching, S.; Krukowska, K. S.; Suib, S. L. Inorg. Chim. Acta 1999, 294, 123-132.

(9) Gaillard, J.-F.; Webb, S. M.; Quintana, J. P. G. J. Synchrotron Radiat. 2001, 8, 928-930.

(10) Gao, Z.-X.; Kim, H.-S.; Sun, Q.; Stair, P. C.; Sachtler, W. M. H. J. Phys. Chem. B 2001, 105, 6186-6190.

(11) Zhou, H.; Shen, Y. E.; Wang, J. Y.; Chen, X.; O'Young, C.-L.; Suib, S. L. J. Catal. 1998, 176, $321-328$.

(12) Krishnan, V. V.; Suib, S. L. J. Catal. 1999, 184, 305-315.

(13) Misaelides, P.; Katranas, T.; Godelitsas, A.; Klewe-Nebenius, H.; Anousis, I. Sep. Sci. Technol. 2002, 37, 1109-1121.

(14) Nelson, Y. M.; Lion, L. W.; Shuler, M. L.; Ghiorse, W. C. Environ. Sci. Technol. 2002, 36, 421-425.

(15) Post, J. E. Proc. Natl. Acad. Sci. U. S. A. 1999, 96, 3447-3454.

(16) Post, J. E.; Bish, D. L. Am. Mineral. 1988, 73, 861-869.

(17) Huang, P. M. Soil Sci. Soc. Am. Spec. Publ. 1991, 27, 191-230. 


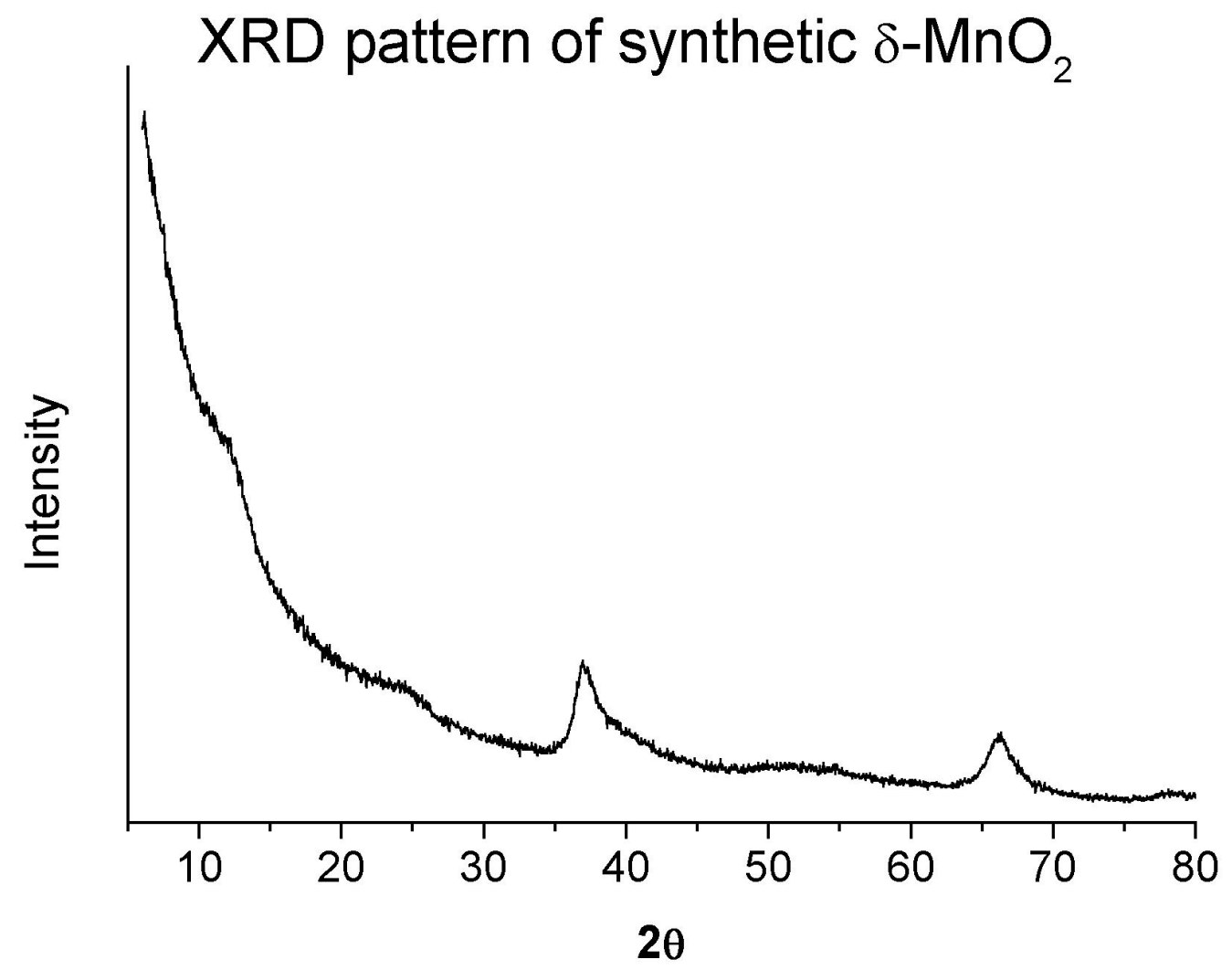

Fig. S1: XRD pattern of the $\delta-\mathrm{MnO}_{2}$ synthesized by precipitation from a colloidal $\mathrm{MnO}_{2}$. It shows characteristic XRD pattern of $\delta-\mathrm{MnO}_{2}$, two broad lines at $2.43 \AA$ and $1.41 \AA$. 


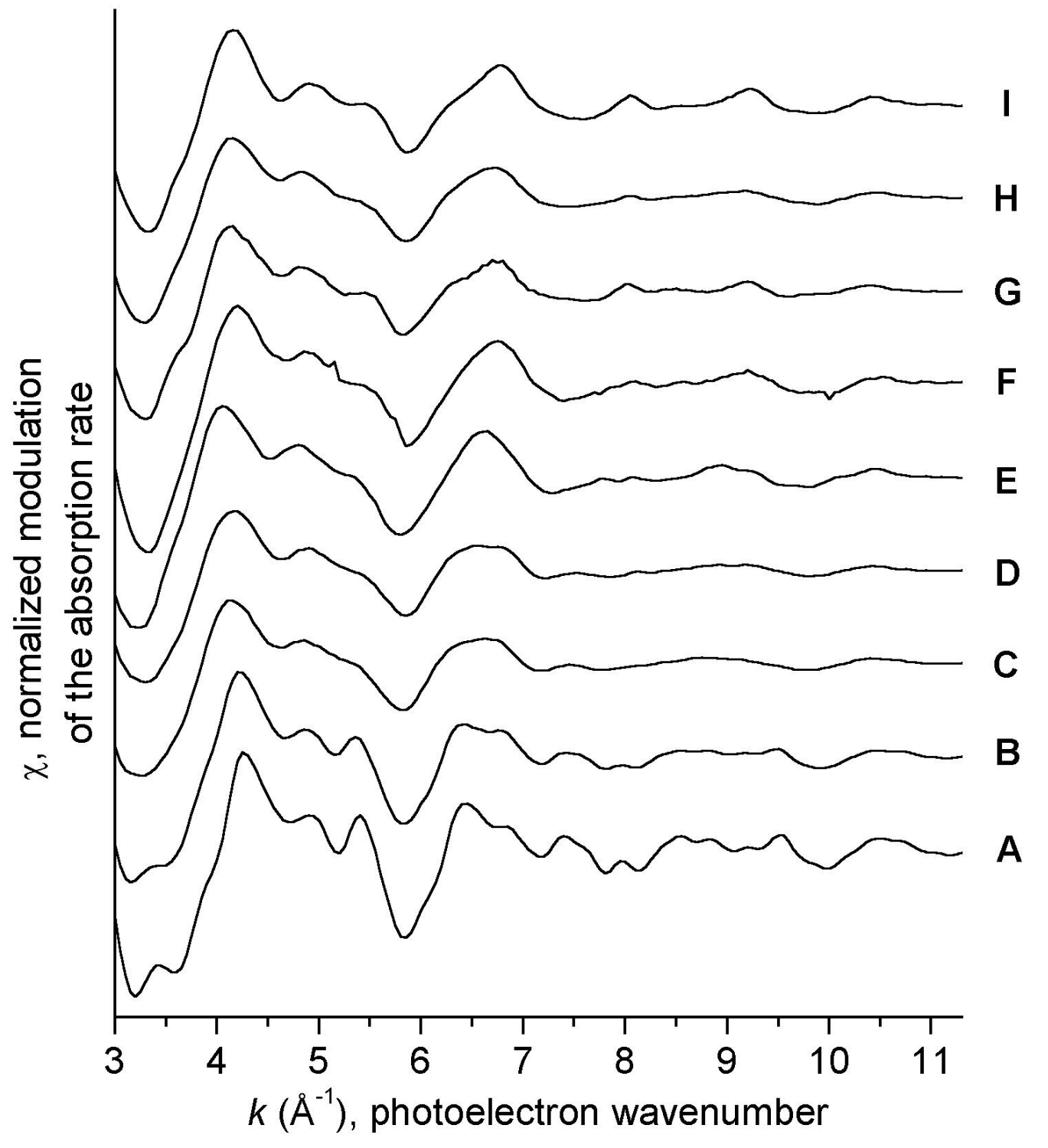

Fig. S2: Mn $K$-edge EXAFS spectra of (A) pyrolusite, (B) ramsdellite, (C) hollandite, (D) romanechite, (E) synthetic birnessite, (F) $\delta-\mathrm{MnO}_{2},(\mathrm{G})$ chalcophanite, $(\mathrm{H})$ todorokite, and (I) SP6- $\mathrm{MnO}_{x}$. 